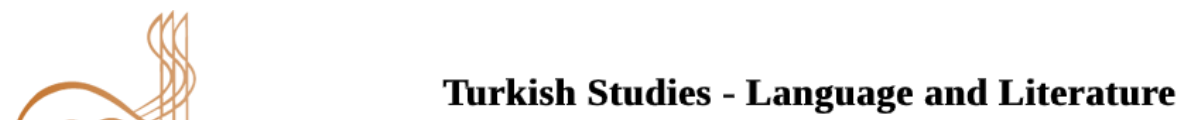

\title{
Fatma Aliye Hanım'ın Refet Romanında İlk Dârülmuallimîn ve Maarif-i Umumiye Nizamnamelerinin İzleri
}

\author{
Traces of Darülmuallimin and Maarif-i Umumiye Ordinances on Ms. Fatma Aliye's Novel Titled \\ Refet
}

\author{
Rabia Gürbüz Us ${ }^{*}$ - Mehmet Özdemir**
}

\begin{abstract}
Significant changes occurred in the field of education in the Ottoman Empire with the Westernization movement during the Tanzimat period. Many innovations have taken part in education, especially the establishment of new schools and the adoption of Western-style education. A series of innovations were also planned after the appointment of Ahmet Cevdet Pasha, the famous politician and intellectual of the Tanzimat Period, to Dârülmuallimîn, which was opened on 16 March 1848 and was the first teacher school. With the Ordinance of Dârülmuallimîn, being one of these innovations, arrangements were made in the operation of these institutions. In addition to the Ordinance of Dârülmuallimîn, the Ministry of Education was established in 1857, and a reform was prepared by continuing a regulation. Traces of this innovation are also found in the novel, Refet, of Ms. Fatma Aliye, the daughter of Ahmet Cevdet Pasha, who was one of the intellectual names of her period. The protagonist of the novel, Refet, goes to Darülmuallimat, a girls' school for teachers, and receives all the necessary training for teaching. In this context, it is aimed to determine the similar aspects of the education the heroine received in the novel with "Ordinance of Dârülmuallimîn", which includes the rules of these schools, and "Maarif-i Umumiye Ordinance", which contains the rules of the education system of the period. In the study, document analysis method, one of the qualitative research methods, was used. In the novel, it was tried to find similarities and / or differences between the education system built and the system established by regulations. As a result of the study, the rules, practices and information contained in the Ordinance of Dârülmuallimîn and Maarif-i Umumiye Ordinance were found in the novel Refet.
\end{abstract}

Structured Abstract: The Tanzimat Period was a period of change and westernization in all aspects of the Ottoman State. With the declaration of the Tanzimat Edict on November 3, 1839, efforts for innovation within the Ottoman State gained momentum. As well as social, economic and political fields education, were affected by these efforts. Although there is no explicit innovation about education in the Tanzimat Edict, the idea of creating a staff consisting of a knowledgeable society and a new intellectual type brought reforms in

\footnotetext{
* Doktora Öğrencisi, Sakarya Üniversitesi, Eğitim Bilimleri Enstitüsü PhD. Student, Sakarya University, Institute of Educational Sciences ORCID 0000-0003-4320-5025 rabiagurbuz@sakarya.edu.tr

*** Dr. Öğr. Üyesi, Sakarya Üniversitesi, Eğitim Fakültesi, Türkçe ve Sosyal Bilimler Eğitimi Bölümü Asst. Prof., Sakarya University, Faculty of Education, Department of Social Sciences and Turkish Language Teaching ORCID 0000-0002-5838-0304

mehmetoz@sakarya.edu.tr

Cite as/ Atıf: Gürbüz Us, R. \& Özdemir, M. (2020). Fatma Aliye Hanım'ın Refet romanında ilk Dârülmuallimîn ve Maarif-i Umumiye Nizamnamelerinin izleri. Turkish Studies - Language, 15(3), 1261-1274. https://dx.doi.org/10.47845/TurkishStudies.42038

Received/Geliş: 06 March/Mart 2020

Accepted/Kabul: 26 September/Eylül 2020

Copyright (C) INTAC LTD, Turkey

Checked by plagiarism software

Published/Yayın: 30 September/Eylül 2020

CC BY-NC 4.0
} 
education to be effective in innovations in other fields (Akyüz, 2013: 159). In this period, progress has been made in many levels from primary education to vocational schools, western-style schools have been opened, and schools providing medical and military education have been established, as well as the training of teachers to teach in these schools.

When we look at the practices of teacher training before Tanzimat, it is seen that there was no systematic teacher training program. The teacher education, which started informally at first, continued with the teachers of the elementary school who were raised in the madrasahs. However, the subject of teacher training had not been placed in a program that could be considered as completely modern. Education in madrasahs and lodges became unable to respond to what was expected of them towards the end of the 16th century (Gündüz, 2015: 21). In 1839, upon understanding that the primary schools were insufficient in terms of education during the Mahmut II period, a decision was made to open the "sinif-1 sani" schools, which are the higher levels of these schools. (Kodaman, 1991: 91). Although these schools are accepted as the upper class of secondary schools, in the following years they were named as secondary education institutions. It was thought that the teachers of the high schools opened in order to give education in a new and modern style should have the knowledge and equipment of modern teaching methods to meet this need. To this end, Dârülmuallimîn, the first teacher school, was opened on 16 March 1848 in Istanbul. Until 1868, no further studies conducted on Darulmuallimin. In 1868, "Dârülmuallimîn-i Sıbyan" schools were opened in order to train teachers to teach at the secondary schools (Koçer, 1991: 79).

With Tanzimat, the education of female students also gained importance. In this sense, girls secondary schools were established in 1868 and girls' education was given in these schools. The teachers who were going to receive education were selected from old and morally trusted men. "This increased the need for female teachers and it felt necessary to open a girls' school." (İlikli, 2010: 60).

In this context, the aim of the study is to investigate the aspects that correspond to the "Ordinance of Dârülmuallimîn" and "Maarif-i Umumiye Ordamname" in the novel Refet. Considering the years when the book was published as serialized, it was thought that it would be more correct to consider the first Darülmuallim Ordinance and the Maarif-i Umumiye Ordiname published in 1869.

Method: In the study, document review method, one of the qualitative research methods, was used. "Document review involves the analysis of written materials that contain information about the phenomenon or facts intended to be investigated. In qualitative research, document analysis can be a single data collection method or it can be used with other data collection methods." (Yıldırım \& Şimşek, 2011: 187).

While collecting the data of the study, the Refet novel of Ms. Fatma Aliye, whose second edition was published in İşbank Cultural Publications in 2019 and adapted by Senem Timuroğlu to today's Turkish, was used.

Findings: Justice in admission of students to school: It was stated in the Ordinance of Darulmuallim that no one would be favored while selecting students. In the novel of Refet, this was stated in the conversation between Refet and her mother.

Transition to Darülmuallimat and learning period: It was possible to reach information about the transition to Darülmualimmat and the duration of education in the novel. The information that the school of Refet will be four years was present. This period was given as three years in the Regulations. In the section on the duration of education, it can be thought that the fiction side of the novel was involved, but it is possible to say that these regulations bear the trail in terms of time.

Lessons given in Darülmuallimat: The lessons stated in the novel that Refet took were similar to the lessons included in the regulations. In addition to the literary composition lesson, she also had art-related lesson and Refet's pencil drawing was another example in the book. There were sentences in the book about the two.

The importance of success order in the appointment: In assigning graduates to the task, taking into consideration the success rankings and scores, was mentioned in the novel

Accordingly, teacher appointments are made starting from the person with high rankings. In the novel, there are expressions to support this situation. 
Evaluation of student behavior: Graduates will be able to work as assistants in Dârülmuallimîn or Darülmuallimat for a salary until they are appointed. There are expressions about this practice in the novel.

Conclusions and Recommendations: Refet differs from other novels of the author in some aspects. The richness that is at the forefront of other novels has been replaced by poverty in this novel. Refet completed her education while fighting this poverty. Another point is that women education in other novels of Fatma Aliye Hanım is handled in a different way in Refet novel. Although most of her novels focus on women's education, this education is generally about home education. However, the training received by the protagonist in her novel was not sufficient, and continued in Darülmuallimat. Fatma Aliye, who was sensitive to the problems of femininity of her period as a woman writer and an intellectual, created a heroine that would be considered an exception with Refet.

Ms. Fatma Aliye, who also included the training given in Darülmuallimat, which was prepared by her father Ahmet Cevet Pasha, through the character of Refet in the work, actually presents many ideas about the education system of the period to the reader. Fatma Aliye actually contributed to the issue of society by giving place in her work by making a purchase according to the success of the student without any favor at the entrance to Darülmuallimat, the lessons given in these schools and how the assignment was after school ended. At some points, the fictional part came to the fore or there were different situations than the information contained in the regulations. However, this situation was less than the overlapping points in the work. When the novel of Refet was viewed from the point of education, it is possible to say that even though it is a fiction, the work of the period is in a structure that sheds light on the education system.

Keywords: Modern Turkish Literature, Ms. Fatma Aliye, Refet, Ordinance of Dârülmuallimîn, Ordinance of Maarif-i Umumiye

Öz: Tanzimat dönemindeki Batılılaşma hareketiyle Osmanlı Devleti’nde eğitim sahasında önemli değişiklikler olmuştur. Özellikle yeni okulların kurulması ve Batılı tarzda eğitimin benimsenmesi gibi birçok yenilik eğitimde yerini almıştır. Tanzimat Dönemi’nin ünlü siyaset ve fikir adamı Ahmet Cevdet Paşa'nın, 16 Mart 1848 yılında açılan ve ilk öğretmen okulu olma özelliği taşıyan Dârülmuallimîn'e müdür olarak atanmasının ardından bir dizi yenilik de planlanmıştır. Bu yeniliklerden biri olan Dârülmuallimîn Nizamnamesi ile bu kurumların işleyişinde düzenlemelere gidilmiştir. Dârülmuallimîn Nizamnamesi'nin yanı sıra, 1857 yılında Maarif-i Umumiye Nezareti kurulmuş ve bir nizamname hazırlanarak eğitim ve öğretimdeki yenileşme hareketleri devam etmiştir. Ahmet Cevdet Paşa'nın kendisi gibi dönemin aydın isimlerinden olan kızı Fatma Aliye Hanım'ın Refet romanında da bu yenileşmenin izlerine rastlanmaktadır. Romanın kahramanı Refet, öğretmen olabilmek için kız öğretmen okulu olan Darülmuallimat'a gitmekte ve burada öğretmenlik için gereken tüm eğitimleri almaktadır. Bu kapsamda Fatma Aliye Hanım'ın kaleme aldığ1 Refet romanınında baş kahramanın aldığı eğitimin, dönemin önemli okullarından Dârülmuallimînler için yazılmış, bu okulların kurallarını içeren Dârülmuallimîn Nizamnamesi ve dönemin eğitim sistemini düzenleyen kuralların bulunduğu Maarif-i Umumiye Nizamnamesi ile örtüşen yönlerinin belirlenmesi amaçlanmıştır. Çalışmada, nitel araştırma yöntemlerinden doküman analizi yöntemi kullanılmıştır. Romanda inşa edilen eğitim sistemi ile nizamnamelerle tesis edilen sistem arasındaki benzerlik ve/ya da farklılıkların bulunmasına çalışılmıştır. Çalışmanın sonucunda Refet romanında, Dârülmuallimîn Nizamnamesi ve Maarif-i Umumiye Nizamnamesinde yer alan kurallar ve uygulamaların benzerlerine yer verildiği tespit edilmiştir.

Anahtar Kelimeler: Yeni Türk Edebiyatı, Fatma Aliye Hanım, Refet, Dârülmuallimîn Nizamnamesi, Maarif-i Umumiye Nizamnamesi.

\section{Giriş}

3 Kasım 1839 tarihinde Tanzimat Fermanı'nın ilan edilmesiyle birlikte Osmanlı Devleti içerisinde yenileşme çabaları hız kazanmış, dolayısıyla Batılılaşma ve değişim bu dönemde ön plana çıkmıştır. Bu çabalardan sosyal, ekonomik, siyasi alanlar kadar eğitim alanı da etkilenmiştir. Her ne kadar Tanzimat Fermanı'nda eğitim ile ilgili açık bir madde olmasa da diğer alanlarda gerçekleştirilen yeniliklerin etkili olabilmesi için bilgili bir toplum ve yeni bir aydın tipi oluşturma düşüncesi eğitimde reformları beraberinde getirmiştir (Akyüz, 2013:159). Bu dönemde, ilköğretimden meslek okullarına kadar eğitimin birçok kademesinde ilerlemeler kaydedilmiş, batılı 
tarzda okullar açılmış, tıp alanında ve askerî alanda eğitim veren okullar kurulmuş, bunların yanı sıra bu okullarda eğitim verecek öğretmenlerin yetiştirilmesi de ele alınmıştır.

Tanzimat'tan önceki öğretmen yetiştirme ile ilgili uygulamalara bakıldığında sistematik bir öğretmen yetiştirme programının olmadığı görülmektedir. Önceleri örgün olmayan şekilde başlayan öğretmenlik eğitimi, daha sonraları medreselerde yetiştirilen sıbyan mektebi hocalarıyla devam etmiştir. Ancak öğretmen yetiştirme konusu modern sayılabilecek bir programa oturtulmamıştır. Medrese, tekke ve zaviyelerde verilen eğitim 16. yy. sonlarına doğru kendinden beklenenlere cevap veremez duruma gelmiştir (Gündüz, 2015: 21). 1839 yılında II. Mahmut döneminde sıbyan mekteplerinin eğitim anlamında yetersiz olduğunun anlaşılması üzerine, bu okulların bir üst basamağı olan sınıf-1 sani okullarının açılmasına karar verilmiştir (Kodaman, 1991: 91). Bu okullar önceleri sıbyan mekteplerinin bir üst sınıfi olarak düşünülse de ilerleyen yıllarda ortaöğretim kurumu olarak rüştiye adını almışlardır. Yeni ve modern tarzda eğitim vermek amacıyla açılan rüştiyelerin öğretmenlerinin de bu ihtiyacı karşılayacak düzeyde bilgiye ve modern öğretim yöntemleri donanımına sahip olması gerektiği düşünülmüş ve bu amaçla 16 Mart 1848 y1lında ilk öğretmen okulu olan Dârülmuallimîn İstanbul'da açılmıştır. 1868'e kadar Dârülmuallimînler üzerinde daha fazla çalışma yapılamamıştır. 1868 yılına gelindiğinde ise sıbyan mekteplerinde ders verecek öğretmenleri yetiştirmek amacıyla "Dârülmuallimîn-i Sıbyan" okulları açılmıştır (Koçer, 1991: 79).

Tanzimat ile birlikte kız öğrencilerin eğitimi de önem kazanmıştır. Bu anlamda 1868 yılında kız rüştiyeleri kurulmuş ve kızların eğitimi bu okullarda verilmiştir. Önceleri kızların eğitim alacağ1 öğrenmenler yaşlı ve ahlakına güvenilir erkeklerden seçilmiştir. "Bu durum bayan öğretmenlere olan ihtiyacı artırmış ve bir kız öğretmen okulu açılması gereği duyulmuştur" (İlikli, 2010: 60).

Maarif-i Umumiye Nizamnamesi ile de kadın öğretmen yetiştirmek amacıyla Darülmuallimat açılması uygun görülmüştür. Buna göre 1870 yılında ilk Darülmuallimat açılmıştır. Dönemin Maarif Nazırı Saffet Paşa bir konuşmasında, kadınların yaratılış icabı her türlü hizmete layık oldukları gibi eğitime de layık olduklarını, erkekler kadar kadınların da eğitim alması gerektiğini vurgulamış, ayrıca kızların eğitiminin dinî açıdan da farz olduğunu belirtmiştir. Bunun yanı sıra erkek ögretmenlerden ders almanın belli bir yaştan sonra sıkıntılı olduğunu ve bunun için kadın öğretmenlere ihtiyaç duyulduğunu da ifade etmiştir (Osman Nuri'den aktaran Özcan, 1992: 457).

Maarif-i Umumiye Nizanmnamesi'nin 68. ve 78. maddeleri, kurulan Darülmuallimat'in işleyişi, ders programı, dersler, mezuniyet, cezalar ve ödüller hakkında bilgi vermektedir. Bu maddelerden öğrendiğimize göre, ilk Darülmuallimat sıbyan ve rüştiye olmak üzere iki sınıftan oluşmuştur ve öğrenim süresi sıbyan sınıfında iki sene, rüştiye sınıfında ise üç senedir. Sıbyan bölümünden mezun olanlar isterlerse öğretmenlik yapabilecek, isterse rüştiye sınıfına geçebileceklerdir. Okula kayıtlar imtihan ile yapılacaktır. Eğitim sonunda mezun olanlar şehadetname alacaklardır (İlikli, 2010: 61; Özcan, 1992: 457).

\section{Ahmet Cevdet Paşa ve Dârülmuallimîn Nizamnamesi}

Tanzimat Dönemi'nin önemli siyaset, ilim adamı ve eğitimcisi olarak tanımlayabileceğimiz Ahmet Cevdet Paşa; 1823 yılında Bulgaristan'ın Lofça kasabasında doğmuştur (Gündüz, 2015: 41). Tanınmış bir ailenin çocuğu olan Ahmet Cevdet Paşa, dönemin önemli âlimlerinden dersler almış ve daha da ilerlemek adına İstanbul'a gelip eğitimine devam etmiştir. Rumeli kazaskerliğine bağlı Premedi kazasında kadılık yaparak iş hayatına başlamış, maarif-i umumiye azası olmuş ve Dârülmuallimîn müdürlügü yapmıştır (Oklay, 2014:236-237).

Ahmet Hamdi Tanpınar'ın, Ahmet Cevdet Paşa hakkındaki cümleleri onu tanımlamaktadır: 
“Cevdet Paşa, Tanzimat'ın ve bilhassa Reşid Paşa devrinin tam adamıdır. O kadar ki, yetiştiği zamanların ayırıcı çizgileri olan telakkilerle bütün hayatını ve eserlerini izah etmek kabildir. Devri gibi teşkilatçı ve hatta muayyen hadler içinde yapıcıdır. Yine devri gibi telifçidir; Avrupa'ya hayrandır, medeniyetçidir, terakkiyi ister; buna mukabil yerli an'anelerin ve hususiyetlerin muhafazasında musırdır. Kıymetler cetveli eskiye sıkı sıkıya bağlıdır." (Tanpınar, 2011: 202)

Ahmet Cevdet Paşa eğitimci yönü nedeniyle eğitim reformlarının içinde bulunan bir kişi olmuştur. "Dârülmuallimîn müdürlüğüne getirildiğinde (14 Ağustos 1850), 1851 yılında Dârülmuallimîn Nizamnamesini yayımlaması ile önemli icraatlara imza atmıştı"” (Halaçoğlu ve Aydın'dan aktaran Koç, 2017: 39). Dârülmuallimîn kurulduktan sonra 1850 yılında müdür olarak görevlendirilen Ahmet Cevdet Paşa, bu görevde iken okulun düzenini sağlayan bazı kuralların olduğu nizamnameyi yazmış ve padişaha sunmuştur (Akyüz, 1990:5). Nizamname metninin başında yine Ahmet Cevdet Paşa tarafından kaleme alınan Nizamname'yi gerekçelendiren ve açıklama niteliği taşıyan yazı bulunmaktadır. Bu açıklamada Dârülmuallimîn'in belli bir amaca hizmet edebilmesi için bazı düzenlemelerin gerekli olduğundan bahsedilmektedir. Bununla birlikte, Dârülmuallimîn öğrencilerinin kaliteli bir eğitim almalarının ve ders çalışmalarının gerekliliği ifade edilmiştir.

Darülmallimin'in kurulduğu dönemlerde "cerre çıkma" öğrenciler arasında yaygın bir durumdu. Bundan dolayı öğrenciler yılın belli zamanlarında İstanbul dışındaki şehirleri gezerek erzak toplamaktaydı. Ahmet Cevdet Paşa, bu durumun Dârülmuallimîn öğrencilerinin ağırbaşlılığı ile ters düşeceğini düşünmüş ve nizamnamede öğrencilerin “dilencilik”ten kurtarılması gerektiğini belirtmiştir. Ayrıca bu durumun öğrencilerin okuldan uzaklaşmasına neden olduğunu ve öğrendikleri bilgilerin de unutulduğunu söyleyerek bu durumdan öğrencileri kurtarmak gerektiğini savunmuştur (Akyüz, 1990:6-7).

Bunların yanı sıra Dârülmuallimîn'den mezun olan öğretmen sayısının rüştiyeler için gerekli olan öğretmen sayısından fazla olduğunu belirten Ahmet Cevdet Paşa, öğrenci sayısının yirmiye indirilmesi gerektiğini de ifade etmiştir. Böylelikle hem ihtiyaç fazlası öğretmen yetiştirmenin önüne geçilmiş olacak hem de her öğrenciye düşen bütçe arttırılabilecektir. Bunun yanı sıra Ahmet Cevdet Paşa, öğrencilere ayrılan bütçenin yetersiz gelmesi durumunda, öğrencilerin yine cerre çıkma ihtimalleri olduğunu düşündüğünden, öğrenci başına düşen para miktarında artış yapılmasının gerekli olduğunu vurgulamıştır. Böylelikle maddi sıkıntıları ortadan kalkan öğrencilerin derslerine daha iyi çalışacaklarını düşünmüsşürr. Ayrıca, tüm bu imkânların cazip gelmesi nedeniyle, hak etmediği hâlde Dârülmuallimîn'e girmeye çalışacak ya da ayrıcalık bekleyecek kişiler için ise kesinlikle iltimas gösterilmemesi gerektiği özellikle vurgulanmıştır (Akyüz, 1990:7-8).

21 Mayıs 1852 tarihinde yürürlüğe giren Nizamname'de talebenin kemiyet ve keyfiyetleri; okula kabul şartları; tahsil süresi ve okutulacak dersler; talebe hakkında icra olunacak muamele ile mezunların durumları bentler hâlinde ele alınmaktadır (Özcan, 1992: 444). Öğrencilerin sayıları ve niteliklerinin belirtildiği ilk bölüme bakıldığında, öğrenci sayısının 20 kişi olarak belirlendiği görülmektedir. Bu 20 kişi muvazzaf olarak belirlenmiştir ve bu öğrencilerin haricinde mülazım öğrencilerin de olduğu Nizamname'ye eklenmiștir. Ancak mülazımlar muvazzafların yerine geçememektedir. Ayrıca alınacak öğrencilerin Arapça bir metni Türkçeye çevirerek anlamını çözebilmelerinin yanı sıra, Farsça ve Matematik bilimlerinde de yetenekli olmaları beklenmektedir.

Nizamname'nin ikinci bölümünde okula mülazım alma şartları yer almaktadır. Bu şartlara göre okula bir mülazım alınırken, baş mülazım kim ise o alınacaktır. Şayet böyle biri yoksa bir sınav yapılacak ve öğrenciler bu sınavdaki sıralamaya göre kaydedilecektir. Ayrıca Dârülmuallimîn'e kayıtlı olan her öğrenci, herhangi bir rüştiyede görev yapacaktır ve okula giriş aşamasında öğrencilere bunu kabul ettiklerini gösteren bir senet imzalatılacaktır (Akyüz, 1990: 1112). 
Üçüncü bölümde öğrenim süresi ve çalışma biçimlerine dair şartlar ele alınmıştır. Buna göre Dârülmuallimînlerin eğitim süresi 3 yıldır ve öğrenciler yılın on ayı, haftada beş gün okulda ders alacaklardır. Ancak mülazımlarda devam şartı aranmamaktadır. Öğrencilere bu eğitim süresi içinde, nasıl ders verileceğine dair bilgilerin yer aldığ 1 Öğretim Yöntemi dersinin yanı sıra Farsça, Matematik, Geometri, Astronomi ve Coğrafya derslerinin de verileceği belirtilmiştir (Akyüz, 1990:12-13).

Dördüncü bölümde öğrencilerin uymak zorunda oldukları kurallar belirlenmektedir. $\mathrm{Bu}$ kurallara göre geçerli bir sebebi olmadan eğitimine devam etmeyen öğrencilerin maaşları kesilecek ve bu öğrenciler okuldan atılacaktır. Ayrıca mezun olan öğrenciler, eğitimlerinin sonunda bir sınava tabi tutulacak ve bu sınavdan geçenler rüştiye hocalığ 1 yapabileceklerine dair diplomaları alacaklardır. Bu diplomalarda okulu kaçıncı sırada bitirdikleri yazılı olacak ve atamalarda bu sıraya dikkat edilecektir. Sınavda başarısız olan öğrencilerin ise okulla ilişiği kesilecektir. Bunun yanı sıra Nizamname'de, her yıl yapılacak bir sınavla rüştiye hocalığı yapabilecek öğrencilerin belirleneceği bilgisi de yer almaktadır. Bu sınava isteyen öğrenciler girecek ve başarılı olmaları durumunda okulu erken bitirip rüştiye hocalığına atanabileceklerdir (Akyüz, 1990: 14).

Nizamname'nin son bölümü olan beşinci bölümde ise mezun olan öğrencilere uygulanacaklar yer almaktadır. Buna göre, öğrenciler mezun olduklarında öğretmenliğe alışmaları için öncelikle yardımcı öğretmenlik yapacaklar, eğer yardımcı öğretmenlikte yer bulamazlarsa bilgilerinin taze kalması için Dârülmuallimîn'e devam edeceklerdir. Rüştiye hocalığına atama yapılacağı zaman, öncelikle ilk sırada mezun olan öğrenciden başlayarak atama yapılacaktır. Eğer ilk boş kadronun olduğu okula gidecek kişi bulunmazsa ilk öğrenci gitmekle mükelleftir. Ayrica öğrenci bu görevi reddederse diploması elinden alınacak ve bir daha okullarda hoca olarak çalışamayacaktır (Akyüz, 1990: 15).

Nizamname'nin şartlarına bakıldığında ilk dikkat çeken özellik, ihtiyaçtan fazla öğrenci alınmaması ve kabul edilen öğrencilerin en iyi şekilde eğitim almalarının sağlanmasıdır. Dikkat çeken diğer bir nokta ise bugün öğretim yöntem ve teknikleri olarak adlandırılan derslerin bu Nizamname ile Dârülmuallimînlere girmiş olmasıdır. Bu durum, öğretim tekniklerinin öneminin fark edildiğini bir kez daha göstermektedir. Ayrıca öğrencilerin sebep yokken okula devam etmemelerini ve mezun olduktan sonra keyfî olarak görev yerine gitmemelerini engellemek amacıyla, okuldan atılma ve diplomaları geri alma cezası getirilmiştir. Bu uygulamalar da eğitimin kalitesini arttırmaya yönelik tedbirler arasında sayılabilir. Ayrıca öğrencilerin okulu bitirme derecelerinin atamalarında etkili olması da günümüz uygulamaları için güzel bir örnek teşkil etmektedir.

\section{Maarif-i Umumiye Nizamnamesi}

Tanzimat Dönemi'nde gerçekleştirilen reformlardan biri de eğitim alanında olmuştur. Yukarıda da ifade edildiği gibi Tanzimat Fermanı'nda eğitim ile ilgili bir madde yer almasa da sonraki yıllarda eğitim konusunda gerekli görülen yenilikler yapılmıştır. Bu yeniliklerden biri de 1857 yılında Maarif-i Umumiye Nezareti'nin kurulması olmuştur (Koçer, 1991: 64). Günümüz Millî Eğitim Bakanlığı'nın temeli olarak nitelendirilebilecek olan Maarif-i Umumiye Nezareti eğitimde kurumsallaşma açısından önem arz etmektedir.

Maarif-i Umumiye Nezareti'nin kurulmasının ardından 1867'den 1871'e kadar Maarif Nazırlığı yapmış olan Saffet Paşa, eğitimi bütün olarak ele almak ve düzene sokmak amaciyla Fransız eğitim sisteminden uyarlayarak Maarif-i Umumiye Nizamnamesi'ni hazırlamıştır (Koçer, 1991: 83). Hazırlanan Nizamname 1869 yılında yayımlanmıştır.

Nizamname, döneminin eğitim ihtiyaçlarını belirlemesi ve eğitime yenilikler getirmesi bakımından eğitim tarihimizde önemli bir yapı taşı olmuştur. Maarif-i Umumiye Nizamnamesi’nin genel hatları şu şekilde ifade edilebilir: 
1. İlköğretim meselesi ele alınmıştır. (mad. 3-35)

2. Ortaöğretim meselesi ele alınmıştır. (mad. 35-50)

3. Öğretmen yetiştirme konusu ele alınmıştır. (mad. 5-78)

4. Bir üniversite kurulması planlanmıştır. (mad. 79-128)

5.Özel öğretim konusu ele alınmıştır. (mad. 128-131)

6. Okullar için gerekli olan kitapları telif veya tercüme yoluyla temin edecek Daire-i İlmiye planlanmıştır. (mad. 133-137) (Çağır ve Türk, 2017: 64)

Nizamname'nin 68. maddesinde kız sıbyan okulları ve kız rüştiyelerine öğretmen yetiştirmek amacıyla Darülmuallimat'ın kurulacağı, müslim ve gayrimüslim olmak üzere iki şubenin açılacağı belitilmiş olup 69. ve 70. maddelerde ise sıbyan okullarına öğretmen yetiştiren kısmın öğrenim süresi iki yıl, rüştiyelere öğretmen yetiştiren kısmın öğrenim süresi ise üç yıl olarak belirlenmiş̧tir (Başbakanlık Devlet Arşivleri Genel Müdürlüğü [BDAGM], 2014: 112). Diğer maddelerde ise Darulmuallimat'ta çalıştırılacak müdür, öğretmen ve diğer çalışanlar ile ilgili bilgiler yer almakta ve maaşlar hakkında bilgi verilmekte; okula giriş sınavları, mezun olan öğrencilerin zorunlu hizmet süreleri ve görevli öğrencilerin alacakları ücretler hakkında bilgiler yer almaktadır.

\section{Fatma Aliye Hanım ve Edebî Kişiliği}

Fatma Aliye Hanım, Osmanlı Devleti’nin son dönemlerinde adından söz ettirmiş önemli devlet adamı Ahmet Cevdet Paşa ile Adviye Rabia Hanım'ın kızıdır. 1862 yılında doğan Fatma Aliye Hanım'ın kendisi gibi yazar olan Emine Semiye adında bir kız kardeşi ve Ali Sedat adında bir ağabeyi vardır.

Yazar, evde ağabeyi için gelen özel hocaların derslerini izleme imkânı bulmuş ve iyi bir eğitim görmüştür. Daha sonra Kolağası Faik Bey ile babasının isteği üzerine evlenmiş, bu evlilikten dört çocuğu olmuştur. Eşinin izni olmadığından ilmî ve edebî yazılarını gizli yazmak zorunda kalmıştır. “Fatma Aliye Hanım'ın gizli gizli okuma ve yazmalarına, gizli gizli tercümeler eşlik etmiş ve Fatma Aliye Hanım yazı hayatına George Ohnet'in Volonte adlı romanını Fransızcadan Meram (1889) adı ile çevirerek 'Bir Kadın' imzasıyla yayımlayarak başlamıştır' (Er, 2011: 385). Aralarında baba-kız ilişkisi bulunan dönemin önemli yazarlarından Ahmet Midhat Efendi ile Hayal ve Hakikat (1892) isimli eseri kaleme almış, bu eseri kaleme aldığında kendi ismini kullanmamış ve esere imzasını yine "Bir Kadın" mahlasıyla atmıştır. (TDV İslam Ansiklopedisi, 2018). Hayal ve Hakikat'in ardından ilk romanı Muhadarat (1892)'1 kendi ismiyle yayımlamış, ardından diğer romanları Refet, Udi, Levayih-i Hayat ve Enîn'i yazmıştır. Fatma Aliye Hanım'ın romanlarının yanı sıra çeşitli gazetelerde yayımlanmış makaleleri ve kadınlara mahsus yazıları da bulunmaktadır.

"Tanzimat'ın ilanıyla birlikte hız kazanan modernleşme döneminde atılan ilk adımlar arasında öncelikle eğitim ve kadınların eğitimi meselesi gelmektedir" (Karaca, 2013: 1487). Fatma Aliye Hanım, özellikle kadının sosyal yaşamda söz hakkının olması, kadının eğitimi ve kadının iş hayatında da rol oynaması üzerine önemli görüşlere sahiptir. Döneminin aydın yazarlarından biri olan Fatma Aliye Hanım, romanlarında da kadın konusunu ele alır. "Fatma Aliye Hanım'ın romanları hem kendi hayatından hem de dönemin toplumsal hayatından izler taşır, ondan beslenir" (Gençtürk-Demircioğlu, 2010: 105). "Kadın erkek eşitliği, kadının eğitimi ve çalışması, evlenme şekilleri, çok eşlilik, boşanma, İslam'da kadının yeri, sosyal hayatta görünür olma gibi kadınlığı doğrudan ilgilendiren konular onun eserlerinin başlıca konusu olmuştur” (Karaca, 2011: 95).

Fatma Aliye'ye göre eğitim; bilgili, kültürlü olmanın yanı sıra hayat pratiğinde de işe yarayacak sonuçları beraberinde getirir. Fâzıla ve Refet örneğinde olduğu gibi ahlakî ve dinî kaidelere uymak, evlendiğinde kocasına denk olmak, zorunlu hâllerde tek başına ve iffetini kaybetmeden hayatına devam etmek gibi hususlar, Fatma Aliye Hanım'a göre eğitimle elde edilen hususlardır (Özger, 2019: 79). Fatma Aliye Hanım, eserlerinde kadının eğitiminin önemini 
vurgulamış ve kadının evde eğitim almasından ziyade okula gitmesi fikrine yoğunlaşmıştır. Ayrıca Fatma Aliye; alınan eğitimin, öğrenilen bilginin hayata yansımasını ve kadınların 'diplomalı çalışan' olmalarını istemektedir (Argunşah, 2016: s.y.). Bu şekilde kadını özel alandan kamusal alana çıkarmaktadır (Babaoğlu-Bekmez, 2019: 9).

Fatma Aliye Hanım'ın kendisini fikirleriyle yönlendiren ve geliştiren manevi babası Ahmet Midhat ile düşüncelerinin ortak olduğu noktalardan biri eğitimdir. Ahmet Midhat'a göre eğitimde en önemli sorun kadın eğitimindeki eksikliktir. "Erkek çocuklar iyi eğitim alabildikleri halde, kız çocukları aynı imkânlara sahip değildirler. Ona göre, "bir milletin milliyeti kadınlar elinde olduğundan' asıl kadın eğitimi daha önemlidir. Ahmet Midhat, eğitilen erkeğin zaman içinde bir gelişim çizgisi izleyeceğine ve kendi seviyesinde bir eş arayacağına işaret eder” (Koç, 2012: 194).

Fatma Aliye Hanım'ın, bir kadın olarak Tanzimat Dönemi'nin en dikkat çeken isimlerinden biri olduğu bir gerçektir. Bu durum ise Fatma Aliye Hanım ve eserleri ile ilgili birçok çalışmanın yapılmasını sağlamıştır. Fatma Aliye Hanım'ın, kadının toplumdaki yeri, kadın hakları, kadınların özgürlüğü, kadının eğitimi hakkındaki düşüncelerinin incelendiği çalışmaların yanı sıra ortaya koyduğu kurmaca eserlerdeki kadın karakterler, bu karakterlerin toplumda, iş hayatında ve aile hayatındaki yerleri; eserlerinde ele alınan değerler ile ilgili yapılmış çalışmalar mevcuttur (bkz. Aydoğdu-Çelik, 2019; Demir, 2013; Er, 2011; Özakın 2019; Özdemir \& Alevli, 2016; Özdemir \& İdi-Tulumcu, 2017; Karaca, 2011; Karaca, 2012; Karaca, 2013). Ancak alan yazında Fatma Aliye Hanım'ın romanlarında Dârülmuallimîn Nizamnamesi ve Maarif-i Umumiye Nizamnamesi'nin izleriyle ilgili herhangi bir çalışmaya rastlanmamıştır. Bu yönüyle çalışmanın alan yazına katkı sağlayacağı düşünülmektedir. Fatma Aliye Hanım'ın kaleme aldığı Refet romanının baş kahramanının aldığı eğitimin, dönemin önemli okullarından Dârülmuallimînler için yazılmış, bu okulların kurallarını içeren Dârülmuallimîn Nizamnamesi ve dönemin eğitim sistemini düzenleyen kuralların bulunduğu Maarif-i Umumiye Nizamnamesi ile örtüşen yönlerinin belirlenmesi amaçlanmıştır. Kitabın tefrika olarak yayımlandığı yıllar göz önüne alınarak ilk Dârülmuallimîn Nizamnamesi ve 1869 yılında yayımlanan Maarif-i Umumiye Nizamnamesi kapsamında ele alınmasının daha doğru olacağı düşünülmüştür.

\section{Yöntem}

Çalışmada, nitel araştırma yöntemlerinden doküman incelemesi yöntemi kullanılmıştır. "Doküman incelemesi, araştırılması hedeflenen olgu veya olgular hakkında bilgi içeren yazılı materyallerin analizini kapsar. Nitel araştırmada doküman analizi tek başına bir veri toplama yöntemi olabileceği gibi diğer veri toplama yöntemleri ile birlikte de kullanılabilir" (Yıldırım ve Şimşek, 2011: 187). Çalışmada, ikinci baskısı 2019 yılında İş Bankası Kültür Yayınları'nda yapılmış olan ve Senem Timuroğlu'nun günümüz Türkçesine uyarladı̆̆ı, Fatma Aliye Hanım’ın Refet romanı kullanılmıştır.

\section{Bulgular}

Refet, Fatma Aliye Hanım'ın kaleme aldığı üçüncü romanıdır. Muhadarat, Udi ve Enîn'de olduğu gibi bu kitapta da kadın konusu önemli yer tutmaktadır. Romanın başkahramanı Refet, çok küçükken babasını kaybeder. Babanın kaybından sonra diğer hanımlarının ve çocuklarının Refet ve annesine eziyet etmesi üzerine annesiyle birlikte İstanbul'a taşınan Refet; ilkokula gitmeye başlar. Dersleri çok iyidir. İlkokuldan sonra sırasıyla rüştiye ve Darülmuallimat'a devam eder. Tüm bu eğitimler sırasında Refet ve annesi büyük maddi zorluklar yaşarlar. Fakirliğin en kötü hâlini görürler ancak annesi Refet'in okuması için elinden gelen her şeyi yapar. Kendilerini kıt kanaat geçindirecek her türlü işte çalışır. Refet okulunu birincilikle bitirir ancak annesini kaybeder. Annesinin ölümünden sonra taşrada bir okula öğretmen olur.

Yazar, kitabın başında bu hikâyenin gerçek bir hayat hikâyesi olduğunu ancak isimlerin değiştirildiğini belirtir:

Turkish Studies - Language, 15(3) 
'Evvela yüce okuyuculara şurasını itiraf edelim: Hikâyeye adını koyduğumuz Refet, serüvenini yazmaya başlayacă̆ımız kızcağızın asıl ismi değildir. Asıl ismin yazılmaması için böyle adlandırdık. Şunu da söyleyelim ki burada Refet'i herkese beğendirmek maksadiyla şöyle güzel, böyle yüksek ahlaka sahip, öyle nazik falan diye hayali bir şahıs tasvirine kalkışmayacağız. Hakikati kopya edeceğiz. Serüven sahibi ne ise onu göstereceğiz.' (s.1)

Genel olarak döneminin roman özelliklerini taşıyan Refet, yalnızca bu yönüyle değil işlediği konuyla ve dönemin eğitim-öğretim faaliyetleriyle ilgili bazı noktaları olay örgüsünün içine alması dolayısıyla da önemlidir. Refet romanında Fatma Aliye Hanım, Darülmualimmat'ta işlenen dersler hakkında çeşitli bilgileri okuyucuya öğrencilerin birbirleriyle ve öğretmenleriyle olan ilişkileri sonucu ortaya çıkan olaylar ve Refet'in eğitim hayatındaki gelişmeler üzerinden vermiştir. Özellikle, bu olay ve gelişmeler babası Ahmet Cevdet Paşa tarafindan hazırlanan Dârülmuallimîn Nizamnamesi'nde yer alan maddelerden izler taşımakta veya zaman zaman Nizamname'deki maddelerle örtüşmektedir. Darülmuallimatların programlarının da Dârülmuallimîn'inkiyle benzeşmesinden dolayı romanda var olan bu izler dikkat çekmektedir. Dârülmuallimîn Nizamnamesi'ndeki maddelerle benzer olan ya da örtüşen maddelerin Refet'te özellikle yer aldığını söylemek veya Nizamname maddelerinin gerçek hayatta ne ölçüde uygulamaya geçirilebildiğini Refet aracıllğıyla saptamak kurgusal bir eserden yola çıktığımız için mümkün değildir ancak Nizamname'de yer alan maddelerin romandaki gelişmelerle örtüşmesi ve kurguda yer alması dikkat çekmektedir. Nizamname'de yer alan maddeler ile romanda örtüşen bölümleri şu şekilde sıralamak mümkündür:

Dârülmuallimîn Nizamnamesi'nin açıklama kısmında daha önce de değinildiği gibi öğrencilerin alımı sırasında kimseye iltimas geçilmeyeceği Ahmet Cevdet Paşa tarafından belirtilmiş ve yazılı olarak padişaha sunulmuştur. Ayrıca Nizamname'nin "Talebe ve Mülazım Yazmanın Usulü” isimli bölümünün birinci bendinde sınavla alım yapılacă̆ hususu da şartlardan biri olarak yer almaktadır. Bu maddeden hareketle, yalnızca başarılı öğrencilerin Dârülmuallimîn'e alınacağını söylemek yanlış olmayacaktır. Romanda ise bu maddede yazılanlar Refet ile annesi Binnaz'ın konuşmalarında şu şekilde yer almaktadır:

“Binnaz - Darülmuallimat mı? O da ne demek?

Refet - Hani ya bizim hoca hanımlar yok mu? İște onların çıktığı okul.

-Ee, onlar çıkmıssa sana ne?

-Nasıl bana ne? Oradan çıkmayınca hoca olunur mu?

-Tamam ama hocalık sana mı kalmış! Hiç bizim gibi fukaralara öyle şey verirler mi?

-Anneciğim kim çalışlyorsa ona verirler." (s.22)

Alıntılanan konuşmada da görüldüğü gibi Binnaz ilk defa Darülmuallimat kelimesini duymakta ve merak etmektedir. Refet annesine öğretmen yetiştiren kurumun Darülmuallimat olduğu bilgisini vermekte, bu okullara hak eden kişilerin girebileceğini söylemektedir. Aynı diyalogda karşımıza çıkan başka bir bilgi ise Refet'in bu okullardan mezun olanların rüştiyelerde öğretmen olduğudur. Nizamname'nin "Müntahabların Ahvali” isimli bölümünde Dârülmuallimînlerden mezun olan öğrencilerin hocası olmayan herhangi bir rüştiyede görev alacağı saptanan şartlardan biridir ve romanın bu diyaloğu da anılan maddeyle uyuşmaktadır.

Romanda Darülmualimmat'a geçiş ve eğitim süresi hakkındaki bilgilere de şu cümleden ulaşılmaktadır:

"Refet rüş̧tiyenin son sınıfinda arzu ettiği gibi birinciliği kazanarak Darülmuallimat'a geçti. Ögretmenlik diploması almaya artık dört sene kalmıştt." (s.58) 
Darülmuallimatların öğrenim süresinin dört sene olduğu ve bu okullara ancak rüştiyelerdeki eğitim tamamlandıktan sonra geçiş yapılabileceği Fatma Aliye Hanım tarafından romanda bu cümle ile ifade edilmiştir. Bu cümlede Dârülmuallimîn Nizamnamesi'nde bulunan maddelerden farklı bir ifade söz konusudur. Nizamname'de eğitim süresinin üç yıl olduğu belirtilmektedir. Ancak Fatma Aliye Hanım bu süreyi romanda dört yıla çıkarmıştır. 1869 yılında çıkarılan Maarif-i Umumiye Nizamnamesi'nin Darülmuallimatların süresi ile ilgili olan 69. maddesinde ise Darülmuallimat-1 Sibyan'ın öğrenim süresinin iki yıl, Darülmuallimat-1 Rüştiye'nin de öğrenim süresinin üç y1l olduğu yer almaktadır (Özcan, 1992: 457; BDAGM, 2014: 112). Koçer (1991) ise Maarif-i Umumiye Nizamnamesi'nde okulun öğrenim süresinin dört yıl olduğunu ancak üç yıl olarak uygulandığını belirtmiştir. Bunun yanı sıra Darülmuallimatların ders programlarıyla ilgili bilgi verilen maddelerde de sıbyan şubesinin öğrenim süresi iki yıl, rüştiye şubesinin üç y1l olacak şekilde planlanmıştır (İlikli, 2010:65-66). Romandaki bu cümleden hareketle Darülmuallimat'a rüştiyeden sonra geçişin Maarif-i Umumiye Nizamnamesi kuralları ile örtüştüğünü söylemek mümkündür. Öğrenim süresinin ise kurgusal bir taraf içerdiğini belirtmek de yerinde olacaktır.

Eserde geçen bir diğer cümle ise Darülmuallimatlara öğrenci alınırken sıbyan ya da rüştiyelerden mezun olmayanların da belli koşulları sağladıkları takdirde Darülmuallimat'a girebilecekleri yönündedir:

“Şule’nin dayısı okumuş yazmış hem de iyice okumuş, ilim âşığ bir kimseydi. Memleketteyken Şule'nin okumastyla ilgilenmiş, iptidai derslerini ve rüştiyede okuyacaklarını kendisi okutmuş̧u. Böylece Şule İstanbul'a geldiğinde imtihan vererek doğrudan doğruya Darülmuallimat'a girmişti." (s. 67)

Maarif-i Umumiye Nizamnamesi'nin 73. maddesinde diploması olanların imtihansız bir şekilde Darülmuallimat'a alınacağı, diploması olmayanların ise bir heyet huzurunda yapılan imtihan sonucu başarılı olmaları durumunda Darülmuallimat'a alınacağı belirtilmektedir. (BDAGM, 2014). Romanda hem Refet gibi rüştiye diploması alıp doğrudan okula girenlere hem de Şule gibi diplomasız ancak belli bir bilgi birikimine sahip kişilerin imtihan ile Darulmuallimat'a kabul edilmesine yönelik örnek verilmiştir.

Romanda Darülmuallimat'ta verilen derslerle ilgili bilgiler de yer almaktadır:

"Bir müddet sonra mümeyyizler geldi, imtihana başlandı. Kitabet imtihanı oluyordu." (s.76)

Maarif-i Umumiye Nizamnamesi'nin 69. maddesinde Darülmuallimatların sibyan şubesinin ders programı verilmiştir ve bu program içerisinde "Kavaid-i lisan-1 Osmani ve kitabet" dersi yer almaktadır. Bu bakımdan romanda Refet'in aldığı dersler Nizamname'de yer alan derslerle uyumludur. Kitabet dersinin yanı sıra son sınıfta sanatla ilgili dersleri olduğu ve Refet'in bu derste karakalem çalışması yaptığı şu cümleden anlaşılmaktadır:

"Refet o sene imtihanına konulacak olan resim manzarasını, ustasından kendisi seçmeyi rica etti. (...) Okulda yaptırılan resim karakalem, sulu boya desendi." (s.107)

Başbakanlık Devlet Arşivleri Genel Müdürlügü’nün (2014) çalışmasında Maarif-i Umumiye Nizamnamesi'nin 71. Maddesinde yer alan Darülmuallimat rüştiye şubesinin ders tablosuna göre, bu okullarda kız öğrencilere Resim dersi verilmiştir. Uygulama ağırlıklı olan resim dersinde, yazılı bir imtihanın yapılmasının düşük bir ihtimal olduğu ve öğrencilerin eserlerinin de sergilendiği göz önüne alındığında, romanda geçen aşağıdaki cümle Maarif-i Umumiye Nizamnamesi'ndeki 71. Madde ile örtüşmektedir:

“... Bir odanın duvarları ögrencilerin el emeği olan resim tablolarlyla donaniyor, diğer bir odanın duvarlart ve masa üstleri de elişleriyle doluyordu." (s.114) 

şekildedir:

Yüksek puanla mezun olmanın getirisinin romanda dikkate sunulduğu bölüm ise şu

"Refet bu elişsinin masrafi için ne yapacağın şaşırmış haldeydi. O sene diploma alacaktı. Maaşı bolca olan birinci ögretmenliğe uygun olmak için notlarının tam olması ve elişinden tam not alması elzemdi." (s.104)

Darülmuallimat'tan birincilikle mezun olup ilk derece öğretmenliğe gidebilmek için bütün notların tam puan olması gerektiği yukarıdaki cümleden anlaşılmaktadır. Bu cümlede ayrıca birincilik derecesi ile mezun olanların daha yüksek maaşlı bir öğretmenliğe atanacağı belirtilmiştir. Ancak ne Dârülmuallimîn Nizamnamesi'nde ne de Maarif-i Umumi Nizamnamesi'nde birinci derecedeki öğretmenliğin maaşı hakkında bilgi bulunmaktadır.

Mezunların göreve atanmalarında başarı sıralamalarının ve puanlarının göz önüne alınacağı hususu -daha önce de belrtildiği gibi- Dârülmuallimîn Nizamnamesi’nin "Müntehabların Ahvali" bölümünün üçüncü bendinde yer almaktır:

"Zuhur edecek mekteb-i rüşdiye hocalığı, baş müntehabın hakkı olduğu gibi, müntehablardan diğer talibi bulunmadığ vakitde, baş müntehab zikr olunan me'muriyyeti kabul etmekde dahi mecbur olacağından, gerek Dersaadet'de ve gerek taşralarda bir mekteb-i rüşdiye hocalığ zuhur edüp, müntehablardan diğer talibi bulunmadığı halde baş müntehab mezkûr hocalığı kabule mecbur olacaktır" (Akyüz, 1990: 15).

Bu kuralın romandaki yansıması ise şu cümlede yer almaktadır:

"Zira işle onu şimdiden bu şekilde geçindirmeye başladiğ gibi, birkaç ay sonra diplomasın alacak ve birici derece diploma aldığında taşraya gitmeye de razı olduğu için bin kuruş kadar maaşla bir birinci ögretmenlik alabilecekti." (s.106)

Romanda, hoş olmayan davranışlar sergilediklerinde öğrencilerin puanlarının kırılacağ 1 ve ceza alacakları anlamının çıkarılabileceği bir bölüm de yer almaktadır:

"Refet bu sözü bağırarak, yumruklarını sıkarak söylüyordu. ... Refet iki ellerini yana salıverip hüngür hüngür ağlamaya başladl. ... Şimdi de güzel ahlak notunun kırılmasından korkuyordu."(s. 113)

Dârülmuallimîn Nizamnamesi'nde böyle bir kuraldan bahsedilmemektedir. Maarif-i Umumiye Nizamnamesi’nin ödül ve cezaların nasıl olacağına dair bilginin verildiği 27 . ve 47. maddeleri arasındaki bölümde, kurallara uygun davranmayan öğrencilere uygulanacak yaptırımlar yer almaktadır. Ancak söz konusu bölümde öğrencilerin puanlarının kırılacağına ilişkin bir bilgi verilmemiştir.

Dârülmuallimîn Nizamnamesi'nin, mezunların durumunun anlatıldığı bölümünde yer alan ikinci bendine göre, mezunlar göreve atanıncaya kadar maaş karşılığında Dârülmuallimînlerde ya da Darülmuallimatlarda yardımcı olarak çalışabileceklerdir. Bu maddenin romandaki karşılığı olarak şu cümle gösterilebilir:

"Birkaç günler sonra Şule ile Refet memuriyetlerine tayin oluncaya kadar ikişer yüz kuruş maaşla okulda muavinlik yapma emri aldılar." (s.124)

Dârülmuallimîn Nizamnamesi'nde mezun öğrencilerin muavinelik ile görevlendirilecekleri belirtilmekte, Maarif-i Umumiye Nizamnamesi'nde ise muavinelerin görevleri hakkında 22.-26. Maddeler arasında bilgi verilmektedir.

Okulda alınan dereceye ve mezuniyet puanına göre atama yapılacağı yine Dârülmuallimîn Nizamnamesi'nin son bölümünde yer almaktadır. Refet romanında bu kural;

"Birkaç gün sonra okulda açılan ögretmenliklerin pusulasını önce sınıf birincisi olduğundan Refet'e gösterdiler." (s. 137) 
cümlesiyle okura sunulmuştur.

Darülmuallimatların kendine has bir düzeninin olduğunu, okul derslerinin sağladığı kazanımın ötesinde, toplumsal ve sosyal olarak da kişiye birçok değer kazandırabileceğini Refet aracılığı ile okuyucuya sunan Fatma Aliye Hanım, şu ifadeleri kullanılmış ve Refet'in gözünden okuyucuya daha derini göstermeye çalışmıştır:

"Geniş bir fikre, kuvvetli bir zekâya malik olan Refet bu okulun haline baktıkça neler düşünüyordu, neler görüyordu. Refet dersi yalnızca hocalardan almakla kalmıyordu. Sabahleyin okulun içi de onun için bir ibret dersi, öğleyin yemekhane de ona bir hikmet kitabesiydi. Her bakış insana her şeydeki hikmet ve ibreti göstermez. Ancak Refet gibi dünyayı bir evren kitabı olarak görenler her şeye dikkatlice ve ibretle bakanlar o kitabın sayfalarında neler görürler, ondan neler ögrenirler! Ah o okulda Refet incelikli baklşlarıyla neler görüyor, neler araştırıyor, neler ögreniyor, ne hikmetler buluyordu." (s. 59)

Yine bir başka kısımda okuldaki arkadaşlık ilişkilerinin nasıl olması gerektiğinden, aynı zamanda bunun öğretmenliğe yansımalarından bahseden bir ifade bulunmaktadır. Fatma Aliye Hanım, bu hususta Refet'in imtihan kâğıdına yazdıklarını okuyucuya ders niteliğindeki şu cümlelerle sunmaktadır:

"Burada kardeşliği öğrenmeli ki ileride birçok vatan evladına annelik ve mürebbiyelik demek olan muallimeliği tanıyabilmeli! Aynı okulda bulunduğu, aynı sıra çalıştığı arkadaşlarına kardeş gözüyle bakamayan ileride öğretmen olduğu zaman da vatanın kızlarını evlat sevgisiyle sevemez." (s. 78)

Aynı imtihan kâğıdının devamında öğretmenlik görevi hakkında yazılanlar da âdeta nasıl bir öğretmen olunması gerektiği sorusunun cevabını vermektedir:

“Öğretmenlik görevi önemli bir meseledir. Insan, görevinin önemli yönlerini tanlyamazsa onu iyi bir şekilde gerçekleştiremez. Öğretmenlik görevini iyi bir biçimde yerine getirmek için öğrencilere sevgi ve şefkat gereklidir. Sanatını sevmeyen kişi sanatkâr olamayacă̆ı gibi, ögrencilerini sevmeyen ögretmen de iyi bir öğretmen ve mürebbiye olamaz.” (s.78)

Romanda yer alan bu ifadelerden de anlaşıldığı üzere, Dârülmuallimîn veyahut Darülmuallimatlar yalnızca bilgi verecek öğreticilerin yetiştirilmesi amacıyla kurulmamış, öğrenciye örnek olacak iyi ahlak sahibi eğitimcilerin/öğretmenlerin yetişmesini amaçlamıştır.

Refet'in imtihan kâ̆ğı üzerinden aslında kendi görüşlerini de yansıtan Fatma Aliye, sonraki bölümlerde ise Darülmuallimatların niçin açıldığından bahsetmektedir:

“Öğretmenlik görevinin önemi düşünüldüğü için Darülmuallimatlar açılmıştır. (...) Darülmuallimat bir bilgi evidir. Nice senelerden beri Osmanlı klzları bilgi sahibi olmak için buraya koşuşturuyorlar. Bu kadar sürede birçok öğretmen meydana getirmişse yüzlerce de bilgili Osmanlı kızı yetişstirmiştir." (s. 79)

Darülmuallimatlar kız okullarına öğretmen yetiştirmek amacıyla açılmasının yanı sıra "Burs almayan öğrencilerini öğretmen olmaya zorlamadığı için, birçok genç kız ve kadın, sadece öğretmen olmak için değil, üst düzeyde bir okulda okumak için bu kuruma girmiş, bu da, ülke kadınları arasında bilgili, aydın bir kitlenin oluşup gelişmesini sağlamıştır.” (Akyüz, 2006: 52).

\section{Sonuç}

Fatma Aliye Hanım, Tanzimat Dönemi’nin getirdiği Batılılaşma düşüncesinin ve içinde bulunduğu toplumun gelenek ve kültürünün sentezlendiği bir kadın imajı oluşturmuş, oluşturduğu bu imajdan hareketle kadın hakları ve kadınların eğitimi gibi önemli konularda toplumda öncü bir aydın olarak yer almıştır. Düşünce ve ideallerini eserlerine de yansıtan Fatma Aliye Hanım, Muhadarat, Udi ve Refet romanlarında ve gazete yazılarında da bu konu üzerinde durmuştur. 
Refet romanının önemli bir noktası, fakirlikle edilen mücadeleye karşın azimli olan kızın eğitimini başarıyla tamamlaması ve kendi ayakları üstünde duran bir kadın olmasıdır. Bir diğer nokta ise kadının eğitiminin farklı bir açıdan işlenmesidir. Romanlarının birçoğunda kadının aldığı eğitim genellikle evdedir ancak Refet'te romanın başkahramanının evde aldığı eğitim yeterli görülmemiş, romanın başkahramanı eğitimine Darülmuallimat'ta devam etmiştir. Bir kadın yazar ve bir aydın olarak döneminin kadın sorunlarıyla hassasiyetle ilgilenmiş olan Fatma Aliye, Refet ile dönemi için istisna sayılabilecek bir kahraman yaratmıştır. Karakterin kamusal alanda kabul gören bir meslek edinerek maddi bağımsızlığını sağlaması ve bu sebeple bir erkeğe eş olmayı tercih etmeyip hayatını kendine yetebilen bir kadın olarak idame ettirmesi kadının erkekten bağımsız kurgulanan kimliğini ortaya koyması açısından son derece önemlidir (Aydoğdu-Çelik, 2019:156).

Eserde Refet karakteri üzerinden, Nizamnâmesi bizzat babası Ahmet Cevdet Paşa tarafından hazırlanan Darülmuallimat'ta verilen eğitimi de olay örgüsü içine yediren Fatma Aliye Hanım, aslında dönemin eğitim sistemi ile ilgili birçok fikri de okuyucuya sunmaktadır. Fatma Aliye; Darülmuallimat'a girişte herhangi bir kayırma olmadan öğrencinin başarısına göre alım yapılması, bu okullarda verilen dersler, okul bittikten sonra atamanın nasıl olduğu ile ilgili Dârülmuallimîn Nizamnâmesi'nde yer alan birçok konuya eserinde yer vererek aslında meselenin topluma mâl olmasına katkıda bulunmuştur. Romanın bazı noktalarında Nizamnamelerden farklı uygulamalar söz konusu olmuştur ancak bu tür istisnalar, Nizamnameler ile örtüşen noktalara nazaran daha azdır. Refet romanına eğitim açısından bakıldığında, eserin dönemin eğitim sistemi hakkında okuru bilgilendirecek ayrıntılarla örülmüş olduğunu söylemek mümkündür.

\section{Kaynakça}

Akyüz, Y. (1990). Dârülmuallimîn'in ilk nizamnamesi (1851), önemi ve Ahmet Cevdet Paşa. Milli Eğitim Dergisi, 95, 3-20.

Akyüz, Y. (2006). Türkiye'de öğretmen yetiştirmenin 160. yılında Dârülmuallimîn'in ilk yıllarına toplu ve yeni bir bakış. Ankara Üniversitesi Osmanlı Tarihi Araştırma ve Uygulamaları Merkezi Dergisi, 20, 17-58.

Akyüz, Y. (2013). Türk eğitim tarihi M.Ö. 1000- M.S. 2013 (24. Basım). Pegem Akademi.

Aydoğdu-Çelik, M. (2019). Tanzimat'tan bir kadın profili: Fatma Aliye Hanım'ın Refet öğretmeni. RumeliDE Dil ve Edebiyat Araştırmaları Dergisi, 5, 146-157. http://dx.doi.org/10.29000/rumelide.606101

Argunşah, H. (8-9 Mart 2016). Tanzimat'tan Cumhuriyet'e kadın yazarlar ve kadınla ilgili konular. Tanzimat'tan Cumhuriyet'e Kadın Şair ve Yazarlar Sempozyum ve Sergisi'nde sunulan bildiri,İzmir.https://www.humed.org.tr/eskisite/TR/Genel/Prof.Dr.HulyaArgunsah169d.pdf ?DIL=1\&BELGEANAH=329\&DOSYAISIM=Prof.Dr.HulyaArgunsah.pdf

Babaoğlu-Bekmez, M. (2019). Türk Edebiyatı'nın ilk romancı kadını Fatma Aliye'nin direnen kadınları. (Yüksek Lisans Tezi). Manisa Celal Bayar Üniversitesi.

Çağır, M. \& Türk İ. C. (2017). 1869 Maarif-i Umumiye Nizamnamesi ve Türk eğitim tarihindeki yeri. Avrasya Sosyal ve Ekonomi Araştırmaları Dergisi, 4(11), 62-75.

Demir, H. (2013). Fatma Aliye Hanım'ın çerçevesinden kadın haklarının sınırları. Turkish Studies, 8 (9), 1059-1068. http://dx.doi.org/10.7827/TurkishStudies.5526

Er, D. (2011). Fatma Aliye (Topuz) Hanım (1862-1936) ve kadının toplumdaki yeri hakkındaki fikirleri. E-Journal of New World Sciences Academy, 6(2), 380-395.

Fatma Aliye Hanım (2019). Refet (Günümüz Türkçesine uyarlayan: Senem Timuroğlu). İş Bankas1 Kültür Yayınları. 
Gençtürk-Demircioğlu T. (2010). Hayattan kurmacaya: Fatma Aliye Hanım'ın dört romanında metinlerarası ilişkiler. Uluslararast Sosyal Araştırmalar Dergisi, 3(13), 104-109.

Gündüz, M. (2015). Eğitimci yönüyle Ahmed Cevdet Paşa. Doğu Batı Yayınları.

İlikli Y. (2010). Osmanlı'dan Cumhuriyet'e öğretmen yetiştirme sorunu (dârü̈lmuallimîn ve darülmuallimatlardan ögretmen okullarına. (Yüksek Lisans Tezi). Gazi Üniversitesi.

Karaca, Ş. (2011). Fatma Aliye Hanım'ın Türk kadın haklarının düşünsel temellerine katkıları. Karadeniz Araştırmaları, 31, 93-110.

Karaca, Ş. (2012). Toplumsal cinsiyet bağlamında Türk romanında kadın öğretmen kimliği Tanzimat ve Cumhuriyet Dönemi romanlarına karşılaştırmalı bir yaklaşım. Karadeniz Sosyal Bilimler Dergisi, 1 (15), 1-15.

Karaca, Ş. (2013). Fatma Aliye ve Emine Semiyye'nin kadının toplumsal kimliğinin kazandırılmasındaki öncü fikirleri, The Journal of Academic of Social Sience Studies, 6 (2), 1481-1499. http://dx.doi.org/10.9761/jasss_760

Koç, E. M. (2017). Ahmet Cevdet Paşa ve Osmanlı Devleti'nde eğitimin modernleşmesi. (Yüksek Lisans Tezi). İstanbul Sabahattin Zaim Üniversitesi.

Koç, M. (2012). 'Üdebâ-yı nisvânın yardımcısı' Ahmed Midhat Efendi ve Fatma Aliye Hanım. Atatürk Üniversitesi Türkiyat Araştırmaları Enstitüsü Dergisi, 48, 191-216.

Koçer, H. A. (1991). Türkiye'de modern eğitimin doğuşu ve gelişimi (1773-1923). Millî Eğitim Basımevi.

Kodaman, B. (1991). Abdülhamid devri eğitim sistemi. Türk Tarih Kurumu Basımevi.

Oklay, E. (2014). Ahmet Cevdet Paşa'nın Türk eğitim tarihi açısından önemi üzerine bir inceleme. Tarih Incelemeleri Dergisi, XXIIX (1), 233-251. https://doi.org/10.18513/egetid.69168

Özakın, D. (2019). Fatma Aliye Hanım'ın Udi romanında kadın özgürleşmesinin sınırları: 'iffet dairesinde' çalıșan kadınlar ve 'ötekiler'. Atatürk Üniversitesi Türkiyat Araștırmaları Dergisi, 64, 271-281. https://doi.org/10.14222/Turkiyat3944

Özcan, A. (1992). Tanzimat Döneminde ögretmen yetiştirme meselesi, 150.yılında Tanzimat. Türk Tarih Kurumu Yayınları.

Özdemir, M. \& Alevli, O. (2016). Fatma Aliye Hanım'ın romanlarında din algısı. Turkish Studies, 11(2), 1013-1028. http://dx.doi.org/10.7827/TurkishStudies.9253

Özdemir, M. \& İdi-Tulumcu, F. (2017). Değerler eğitiminde edebi eserlerden yararlanma: Fatma Aliye'nin Muhadarat romanı örneği. Sakarya University Journal of Education, 7 (4), 720 729. http://dx.doi.org/10.19126/suje.377548

Özger, Z. (2019). Fatma Aliye Hanım'ın felsefí görüşleri. (Yüksek Lisans Tezi). Ankara Yıldırım Beyazıt Üniversitesi.

Tanpınar A. H. (2011). Edebiyat üzerine makaleler (haz. Zeynep Kerman). Dergâh Yayınevi.

T.C. Başbakanlık Devlet Arşivleri Genel Müdürlüğü [BDAGM] (2014). Arşiv belgelerine göre Osmanlı eğitiminde modernleşme. Osmanlı Arşivi Daire Başkanlığı Yayın Nu: 134 https://www.devletarsivleri.gov.tr/varliklar/dosyalar/eskisiteden/yayinlar/osmanli-arsiviyayinlar/134_OSMANLI\%20E\%C4\%9E\%C4\%B0T\%C4\%B0M\%C4\%B0NDE\%20Moder nle\%C5\%9Fme.pdf

TDV (2018). TDV İslam Ansiklopedisi. https://islamansiklopedisi.org.tr/fatma-aliye-hanim

Yıldırım A. \& Şimşek H. (2011). Sosyal bilimlerde nitel araştırma yöntemleri (8. Basım). Seçkin Yayınc1lik. 